\title{
PETROGRAPHIC CHARACTERIZATION OF ROCKS FROM THE MIRABELLO BAY REGION, CRETE, AND ITS APPLICATION TO MINOAN ARCHAEOLOGY: THE PROVENANCE OF STONE IMPLEMENTS FROM MINOAN SITES
}

\author{
Dierckx H. M. C. ${ }^{1}$, and Tsikouras B. ${ }^{2}$ \\ ${ }^{l}$ Elmira College, Division of Humanities, One Park Place, Elmira, New York 14901, U.S.A., \\ hdierckx@elmira.edu \\ ${ }^{2}$ University of Patras, Department of Geology, Section of Earth Materials, GR-265 00 Patras, \\ Greece,v.tsikouras@upatras.gr
}

\begin{abstract}
The Minoans of East Crete used a variety of igneous and metamorphic rocks as stone implements. These were probably procured in dry riverbeds and beaches located in a region along the Bay of Mirabello or from an onlap conglomerate, which geologically dominates that region and contains rock types of igneous, metamorphic and sedimentary origin. Several rock samples were collected for petrographic investigation to examine and confirm the source for the igneous rocks. Detailed petrographic description of natural samples provides the identification of the rocks employed by Minoans and confirms the source of their origin. Apparently the Minoans were able to evaluate the hardness of the stones procured according to the desirable usage and their expected fatigue, thus avoiding unnecessary timeconsuming treatment. The identification of the variable lithotypes used for these implements and the verification of their source regions reveal the time it took to procure the raw materials as well as the time period during which the rocks were employed.
\end{abstract}

Key words: Petrography, Minoan Archaeology, ground stone implements, Crete.

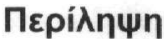

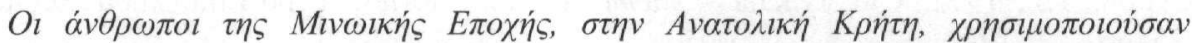

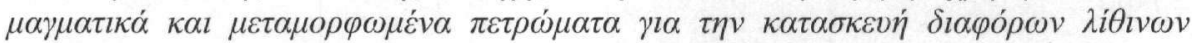

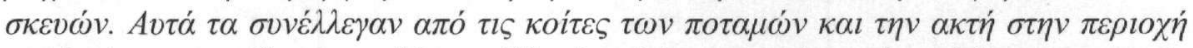

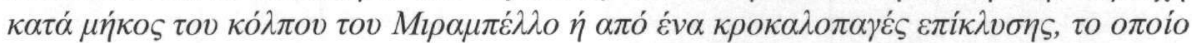

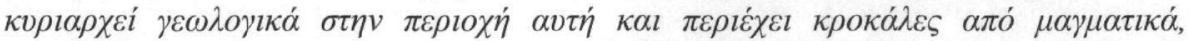

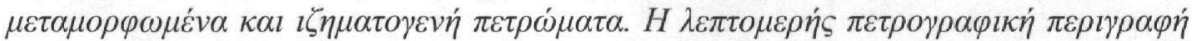

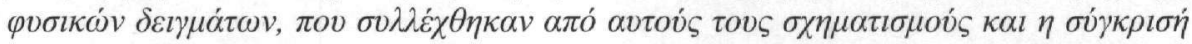

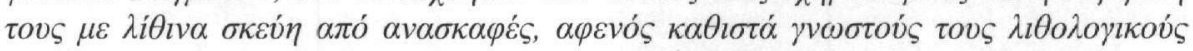

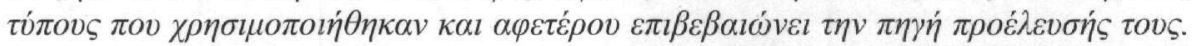

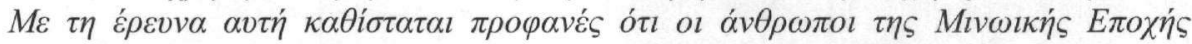

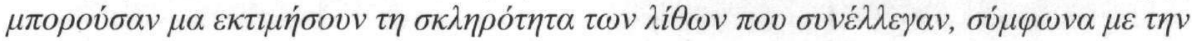




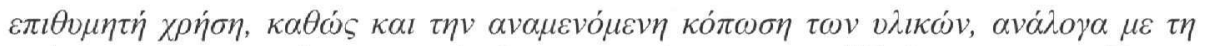

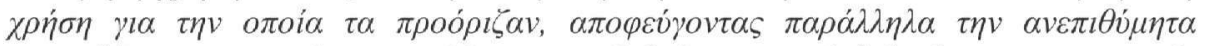

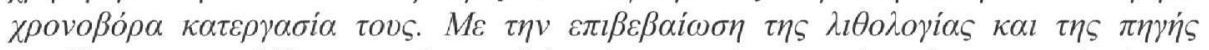

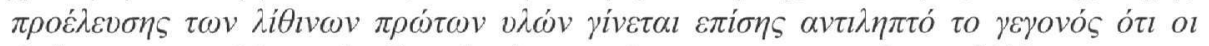

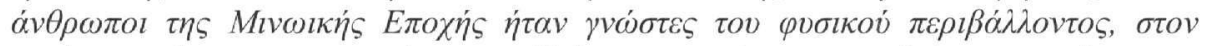

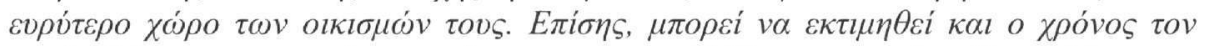

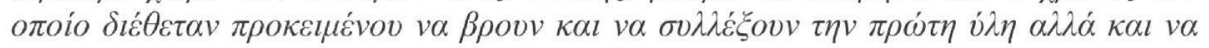

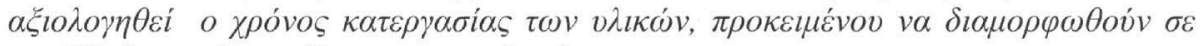

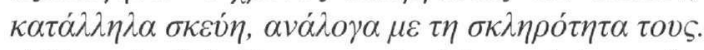

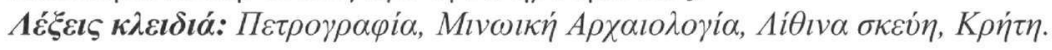

\section{Introduction}

Geology, specifically the field of petrography, is very valuable with the increased interest in the study and publication of Minoan ground stone implements. Such studies have started to move beyond mere description and classification. Likewise, contemporary research examines the contextual environment of these implements, in an attempt to identify and analyze the raw materials used for their manufacture and to locate their possible sources. This task, however, requires the collaboration of geologists and petrographers. The aim is to answer the following questions: How far did people travel to find suitable materials for tool manufacture? What are the kinds and amount of sources available? Why were certain types of rocks used and when?

In this article we examine the ground stone implements from a number of east Cretan sites ranging in date from Late Minoan to the Iron Age (c. 2000-1000 BCE.). Stone implements made from a variety of igneous and metamorphic rocks were found among the ground stone tool assemblages from several of the archaeological sites. In order to explore and prove their source region, 80 rock samples were collected for petrographic investigation, along the region of the Mirabello Bay and other regions in Crete, with similar rock types (most notably the Asteroussia mountains).

In this study, we will discuss the onlap conglomerate of the Mirabello Bay area in detail, and we will reveal the results of the petrographic characterization of the various rock types contained within this deposit. Petrographic comparison of its lithotypes that comprise both the conglomerate and the stone implements will provide not merely the identification of the various rock types used by the Minoans as stone implements but also important evidence as to the sources of the pebbles and cobbles from which the tools were made, the time it took to travel for the procurement of the raw materials, and information as to whether any or all the types of rocks were used at a specific historical time period. Moreover, the detailed petrographic description of the rocks from the onlap conglomerate may function as a database for future archaeological work.

\section{Geological Setting of the Mirabello Bay Region}

Crete has a rather complicated geology since five tectonic nappes (i.e. the Tripali Unit, PhylliteQuartzite Series, Tripolitza Zone, Pindos Zone and Arvi Ophiolite Unit) have been superimposed on the basement consisting of the Talea Ori-Plattenkalk Unit (e.g. Seidel et al. 1981, 1982, Fassoulas et al. 1994). The autochthonous (or parautochthonous) basement of the Talea OriPlattenkalk Unit is composed of semimetamorphic formations of Permian to Eocene age that probably belong to the Ionian isopic zone of the Hellenides. The Tripali Unit, the PhylliteQuartzite Series and the Plattenkalk Series have been affected by Oligocene to early Miocene HP/LT metamorphism (Seidel et al. 1982, Theye et al. 1992, Theye and Seidel 1993) and related deformation (Fassoulas et al. 1994, Kilias et al. 1994, Stöckhert et al. 1999, Zulauf et al. 2002).

Field work revealed that the eastern part of the Mirabello Bay is dominated by the presence of the Phyllite-Quartzite Series and the Plattenkalk carbonate rocks, while the central and western areas of the Bay are mainly occupied by Cretaceous limestones of the Tripolitza Zone, intruded by 
dioritic to granodioritic rocks, as well as covered by Miocene to Pliocene detrital sediments (Fig. 1). The Phyllite-Quartzite Series contains mica-schists, gneiss, amphibolite and marble. These rocks have been thrust over the Plattenkak Unit composed mainly by marbles. The members of the Tripolitza Zone lie above the Phyllite-Quartzite Series via a tectonic contact that has been interpreted either as a detachment fault (Fassoulas et al. 1994, Jolivet et al. 1996) or thrust (Campbell et al. 2003, Klein et al. 2004), and comprise, from bottom to Top, Triassic dolomite, Cretaceous limestone and Flysch of Eocene age. Small, intensively weathered, plutonic bodies of dioritic to granodioritic composition intrude the limestone, causing locally contact metamorphic phenomena. The ophiolitic Arvi Unit is represented in the area by a small outcrop of dolerite. Miocene and Pliocene formations, mostly conglomerates of marine origin and occupying tectonic basins, cover all the previous rocks. A Miocene onlap conglomerate contains pebbles of variable composition and shape. It is composed of pebbles that vary in size from $4 \mathrm{~cm}$ to $30 \mathrm{~cm}$, but are usually at around $7-10 \mathrm{~cm}$. Notably and unlike their source outcrops, these pebbles are fresh, due to replenishment during their transportation and are surrounded by yellowish clay to sandy matrix. Pebbles include basalt, dolerite, gabbro, diorite, granodiorite, amphibolite, sandstone (including quartz-sandstone), limestone, quartzite and various types of schists. Some pebbles are reddish diorite and along with basalt, dolerite and gabbro have not been observed as major outcrops in the immediate vicinity. At places, this formation shows stratification and lies unconformably above the Cretaceous limestone and the diorite-granodiorite outcrops.

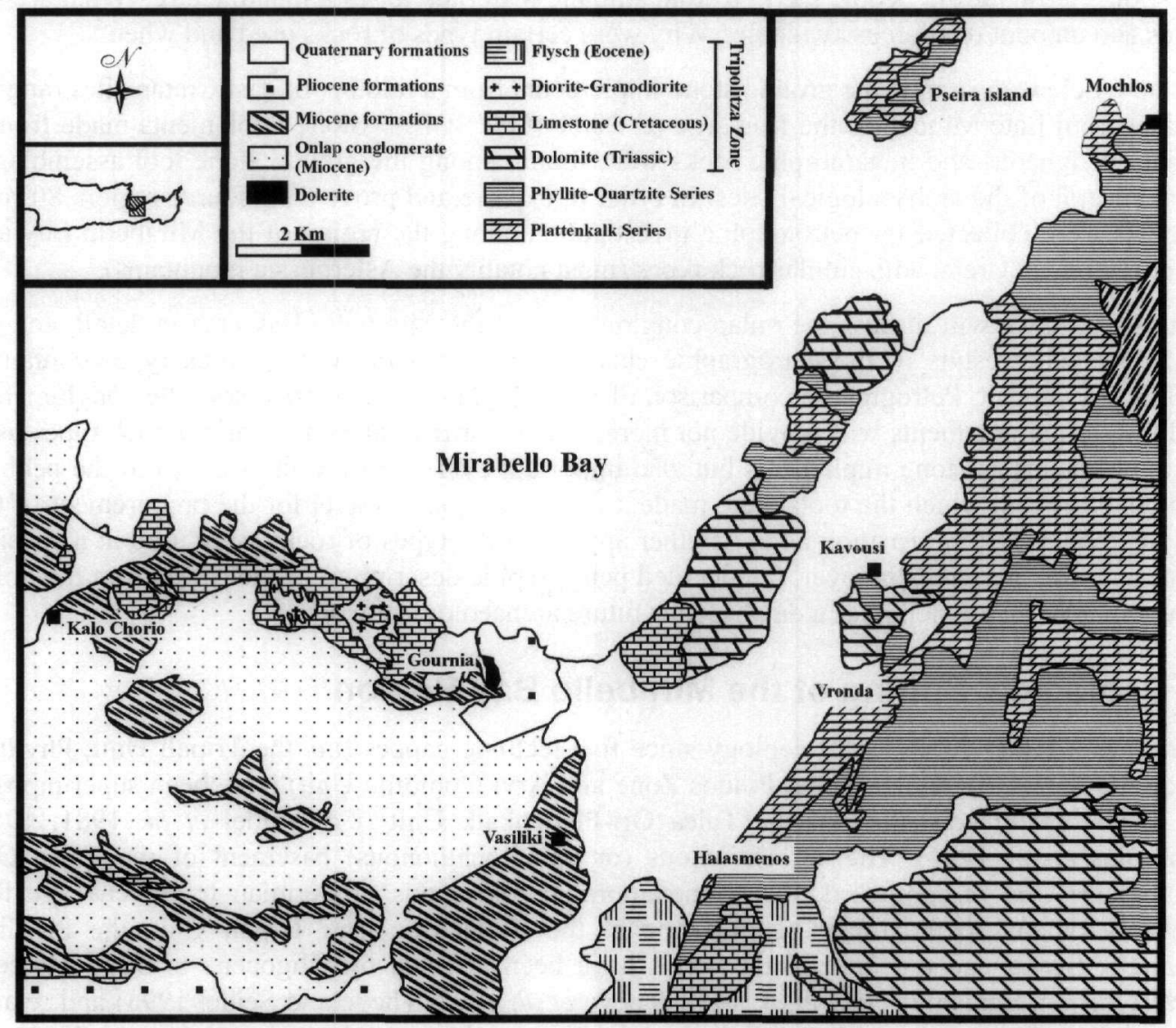

Figure 1 - Simplified geological map of the Mirabello Bay (after I.G.M.E. 1959) 


\section{Petrographic characterization of the rocks}

The onlap conglomerate contains a large variability of rock-types; however we present here macroscopic and polarizing light microscopic, petrographic features of samples that, due to their hardness, have been used as tools. The archaeological implements have been macroscopically examined and compared to natural samples, until permission is acquired to sample them and prepare thin sections.

\subsection{Basalt}

The basaltic samples are macroscopically microcrystalline, mostly homogeneous, dark-colored (usually black, dark brown or red; Fig. 2a, b). Some of them show a dotted appearance, due to the presence of amygdules filled with white calcite (Fig. 2b) while other samples are intersected by whitish or greenish veins. The samples with reddish tinge are due to impregnation from Fe-oxides. They are fine-grained rocks which display a textural variety like intermediate, intergranular, porphyritic and microcrystalline. The samples with intermediate texture contain lath-shaped to needle-like plagioclase and clinopyroxene grains (sometimes quench) that form a net. The interstices are occupied by amorphous groundmass. The rocks with intergranular texture contain plagioclases that form a net with the interstices filled by clinopyroxene grains. The porphyritic samples contain phenocrysts of plagioclases and clinopyroxenes while the groundmass is composed of very fine grains of the same minerals along with glass. Plagioclase participates in approximately $40-70 \mathrm{vol}$. \% and clinopyroxene up to 45 vol. \%. Opaque (metallic) minerals (up to 3 vol. \%), presumably magnetite and ilmenite, are also present almost in all samples. Zircon and titanite occur as accessory minerals.

\subsection{Dolerite}

The dolerites are dark colored, fine-grained, holocrystalline rocks (Figs 2c, d). Macroscopically, they contain fine-grained greenish pyroxene (altered) and whitish plagioclase. Rare capillary and broader veins are present. They represent rocks texturally transitional between gabbros and basalts. They display subophitic texture where the plagioclases (40-65 vol. \%) form a net with the interstices filled with clinopyroxenes (up to $40 \mathrm{vol}$. \%), mainly altered to actinolite and chlorite. Some samples show locally porphyroid texture with subophitic groundmass. Frequently plagioclases show optical zonation. Opaque minerals (probably magnetite and ilmenite up to 3 vol. $\%$ ) and accessory zircon and titanite occur, too. Alteration is variable and can reach to the formation of actinolite up to $35 \mathrm{vol}$. \%, after clinopyroxene. Besides actinolite, chlorite and infrequent hornblende are also alteration products of the clinopyroxenes. Several times, the pyroxenes are totally altered to pseudomorphic actinolite. The plagioclases are altered to albite, epidote, sericite and quartz. In some samples, chlorite is sparsely dispersed in plagioclases. Some samples contain also veins of quartz, albite, chlorite and epidote.

\subsection{Gabbro}

These samples are mostly inhomogeneous, rather coarse-grained comprising whitish plagioclase and greenish to dark, altered pyroxene (Figs 2e, f). They show variation in their color index depending on the relative amounts of plagioclase and pyroxene. Some of them are penetrated by whitish veins filled with calcite. They are medium-grained rocks with granular, hypidiomorphic or subophitic textures and consist mainly of plagioclase (up to $85 \mathrm{vol} . \%$ ) and relics of clinopyroxene crystals (up to $40 \mathrm{vol}$ \%). Rarely, some samples display poikilitic texture where altered clinopyroxene crystals include plagioclases. Locally, the clinopyroxene crystals are fragmented. Few samples show local zones of brittle deformation with intensively fragmented grains of clinopyroxene and plagioclase and the development of secondary quartz. Magnetite and accessory zircon and titanite complete the assemblage of these rocks. Alteration is significantly intense and its products include albite, quartz, calcite sericite, clay minerals and more rarely epidote and muscovite after plagioclase. The clinopyroxenes are altered to actinolite (10-40 vol. \%), chlorite 
(3-15 vol. \%) and sparsely to tremolite (3-8 vol. \%) and hornblende. Pseudomorphic replacements of actinolite and chlorite after clinopyroxene are frequent. Rare Fe-Ti oxides are dispersed in some samples. Sparse epidote veins are also present.
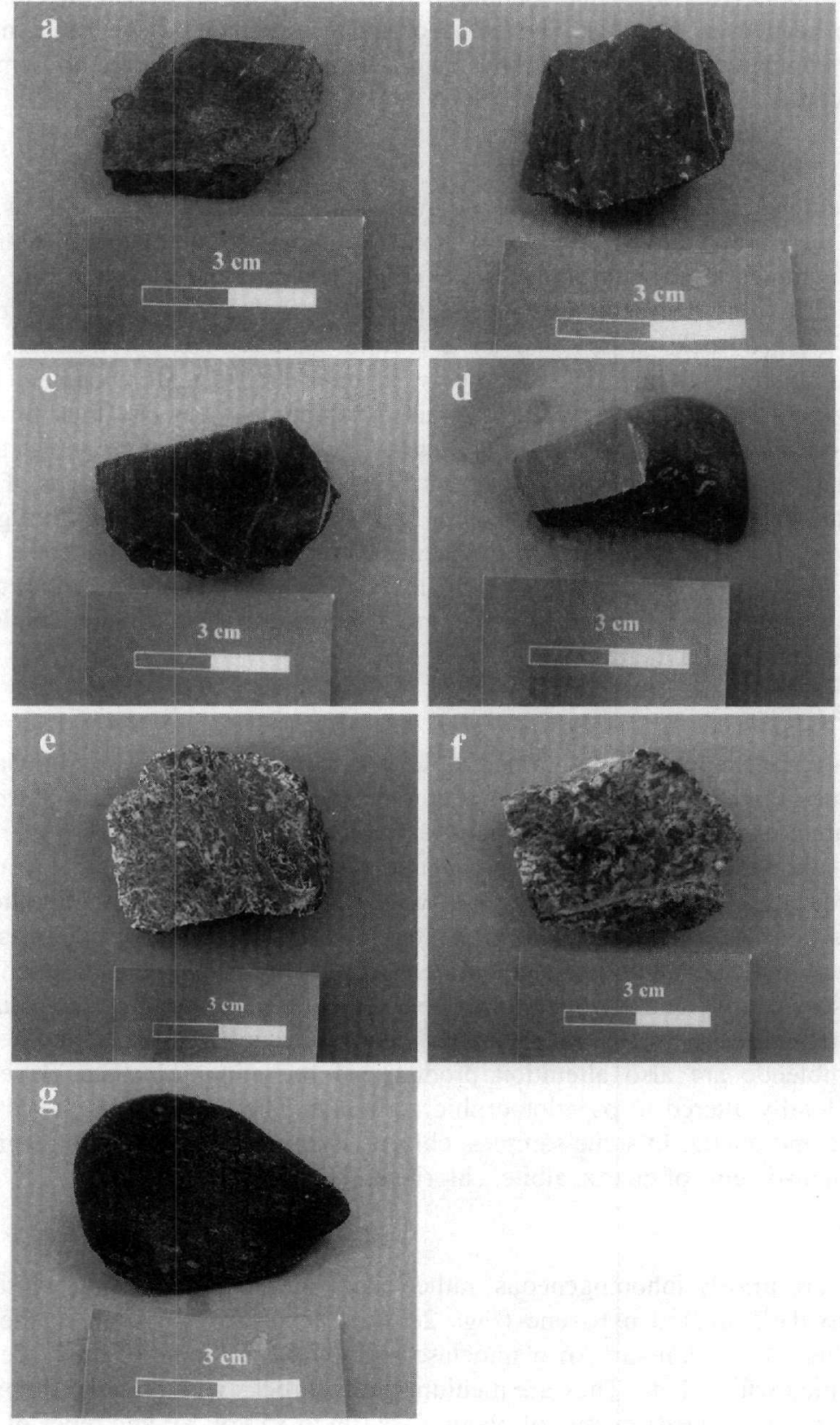

Figure 2 - Macroscopic views of representative samples collected from Mirabello Bay: a,b: basalts; c,d: dolerites; e,f: gabbros; g: amphibolite

\subsection{Amphibolite}

The amphibolite samples are characterized by well developed foliation and contain fine- to medium-grained, green hornblende, which is the dominant component; thus it governs their color (Fig. 2g). Feldspar crystals are also visible. Some samples contain veins filled with whitish calcite. 
The amphibolites display typical lepidoblastic textures where hornblende (40-60 vol. \%) dominates. Plagioclase (15-50 vol. \%) and quartz (5-12 vol. \%) are always present while actinolite (up to 10 vol. \%), epidote (including clinozoisite, up to 5 vol. \%), opaque minerals (up to 5 vol. \%) and lesser amounts of calcite, biotite occur in several samples. Exceptionally, one sample (RS $05 / 38$ ) is extremely rich in epidote (approximately 30 vol. \%) and poorer in hornblende. In many cases amphibole and plagioclase crystals, which are the dominant minerals, are roughly oriented, as an indication of a probable igneous (i.e. gabbroic rock) protolith. Accessory zircon, titanite and apatite are also present while sample RS 05/33 contains additionally about 3 vol. \% rutile. The occurrence of titanite is additional evidence for the hypothesis of a gabbroic protolith. Distinctly, sample RS $05 / 73$ contains relic crystals of igneous clinopyroxene that are partially transformed to hornblende, due to incomplete equilibration. Retrograde products are chlorite after hornblende and sericite, clay minerals and albite after plagioclase. Moreover, sample RS 05/73 contains veins filled with calcite and actinolite, as well as others with calcite and prehnite.

\subsection{Diorite-Granodiorite}

These samples are generally felsic with almost equal amounts of leucocratic and melanocratic minerals and comprise a complete variation from diorite to granodiorite. Exceptionally, two dioritic samples (RS 05/62 and RS 05/70) are dark since they contain a larger proportion of mafic components. Some samples show a reddish tinge, due to impregnation by secondary Fe-oxides. The leucocratic minerals are plagioclase and quartz, while the melanocratic ones are hornblende and biotite in various proportions. Typically, the minerals are almost equally distributed in the samples, thus displaying a rather uniform appearance. Several samples are veined with whitish material.

Microscopically, the diorites are medium- to coarse-grained rocks with granular, subhedral texture. Exceptionally sample RS 05/62 shows porphyroid texture with porphyroid crystals of plagioclase set in a finer-grained, granular mass. Their assemblage includes plagioclase, hornblende, biotite, quartz and K-feldspar in variable proportions. The mass in the sample with porphyroid texture also contains the same constituents, while the porphyroid plagioclase contains locally hornblende inclusions. According to their prevailing mafic mineral they are subdivided in three groups: Hornblende-diorites are dominated by hornblende (15-45 vol. \%) while biotite participates from about 1 vol. \% to 10 vol. \%. Plagioclase constitutes around 55-80 vol. \%, K-feldspar up to 10 vol. $\%$ while quartz participates up to 15 vol. \%; opaque minerals occur up to 4 vol. \%. Typically in these samples, biotite crystals are clearly smaller relative to hornblende. Biotite-diorites are characterized by the presence of biotite from 10 vol. $\%$ to 20 vol. $\%$ while hornblende is much less, up to 5 vol. \%; plagioclase makes up 50-70 vol. \%, quartz 5-15 vol. \% and opaque minerals up to 2 vol. \%. Biotite-hornblende diorites are transitional between the two other lithotypes, where the biotite amount increases relative to that in the hornblende-diorites, but remains lower than hornblende. In all rock-types, there are plagioclases that show optical zoning while in several cases plagioclases with polysynthetic twinning show kinking, due to deformation. Microcline is frequently present in the samples. Characteristic myrmekite intergrowths of plagioclase and vermicular quartz are also observed while usual perthitic exsolutions from K-feldspar occur, too. In almost all samples apatite, titanite and zircon occur as accessory phases. Igneous hornblende is green and/or brown and usually is altered to actinolite and chlorite, frequently forming pseudomorphic crystals. The secondary actinolite displays a patchy appearance, thus it is distinguished from the primary hornblende. In hornblende diorites, the biotite crystals are commonly partially or totally altered to chlorite and Fe-oxides and very rarely to muscovite. The plagioclases have been saussuritized and replaced by albite, sericite, quartz and clay minerals and more rarely by calcite and muscovite. Calcite is also present in veins or dispersed throughout the thin section. Opaque minerals (probably magnetite and ilmenite) have been oxidized to $\mathrm{Fe}-\mathrm{Ti}$ oxides.

The granodiorite samples differ in having higher amounts of quartz. They display granular, hypidiomorphic texture and contain mainly plagioclase (55-65 vol. \%), quartz (20-25 vol. \%), K- 
feldspar ( $8-15$ vol. \%), biotite (5-8 vol. \%) and hornblende (up to 3 vol. \%). K-feldspar is frequently present in the form of microcline. Perthitic formations and myrmekitic intergrowths of quartz and feldspar occur, too. Opaque minerals are present in minor amounts, as well as accessory zircon, titanite and apatite. Exceptionally, sample RS 05/31 contains zones of intense brittle deformation. Secondary minerals include quartz, albite, sericite, and clay minerals after plagioclase, as well as chlorite and Fe-oxides after biotite.

\section{Application in archaeology}

The study focuses on the investigation of a little over a thousand ground stone tools from three archaeological sites in East Crete, ranging in date from the Late Minoan into the early Iron Age. The sites include Vronda and Kastro (Kavousi) and Halasmenos. From this study, the following basic observations have been made.

The majority of stones from which the tools are made consist mostly of water worn limestone, crystalline limestone or quartzite pebbles and cobbles, but also include examples of basalt, dolerite, gabbro, and amphibolite, as well as minor schists. Basalt, dolerite, gabbro and amphibolite comprise typical members of an ophiolite suite, which, however, is no longer present in close proximity to the investigated area. Amphibolite occurs also in the phyllite-quartzite series together with quartzite and schists. The most extensive ophiolite outcrops (Arvi Unit) are present in central Crete, about $45-50 \mathrm{~km}$ to the west of the region of the Mirrabello Bay (Seidel et al. 1981, Koepke et al. 1985). However, these rock-types, along with various schists, quartzite and limestones are abundant in the nearby Miocene onlap conglomerate and on beaches or in dry riverbeds located not far from the settlement sites (Fig. 1). This conglomerate appears to be of major interest since it contains mostly unweathered pebbles that have the proper size, i.e. are able to fit in one hand, and the proper hardness (variable between 6 and 7 on the Mohs' scale), to have been used as tools. In most instances, these pebbles and cobbles were not worked before being used as tools, since the ancient people chose stones of the right size and shape. Most were multifunctional and exhibited the same use wear patterns of pecking and/or abrasion. These tools have been generally labelled pounders, pestles, grinders, whetstones, polishers, or querns.

The stone implements can be divided into 16 main groups or types. Two central attributes that underlie the typology of the ground stone implements are most importantly the wear marks (e.g. pecking, abrading, flaking; for explanations see Appendix) and/or shape and size of the tools, leading to a possible functional interpretation of the tool. Raw materials may become a secondary variable creating subdivisions within the main types. Interpretative functions are added for clarification.

Some general patterns can be discerned as to the correlation between the different tool types and the raw materials used. In general, it can be noted that grainy textured rocks, such as the most commonly used quartzite and quartz sandstone, were used for grinding/abrading/polishing (for explanations see Appendix), resulting in the pulverizing and removal of excess material. Carbonate rocks, such as limestones, were used for pounding and hammering, though it was also preferred for weights. Schist (green schist and calcareous schist) was mostly preferred for whetstones and choppers. On the other hand, igneous and metamorphic cobbles, which are hard and dense, were preferred for facetted tools and special shapes, such as polishers and celts. Facetted tools, polishers and celts were most common in dolerite, gabbro, amphibolite and basalt, whereas basalt pebbles and cobbles were used in pounder-pestles/polishers. Hence, the physical qualities of the rock types account for the preference of certain rocks for stone tools.

Although limestone and quartzite are abundant near the archaeological sites of the Mirabello Bay region, the mafic and metamorphic (amphibolite) rocks occur only in the Miocene onlap conglomerate and the streams downward. The natural samples collected show considerable macroscopic similarities to the materials of the stone tools, hence, it is strongly suggested that this conglomerate may had been an important source for the Minoan people to collect stones for their 
tools. However, further destructive methods on the tools themselves, such as microscopic and geochemical investigation, would provide additional evidence for this hypothesis.

Five classes of implements can be distinguished by their use of igneous and metamorphic raw materials, four of which were extensively altered from their natural form. These rocks were chosen primarily for their hardness (ranging from 6 to 7 on the Mohs' hardness scale) and durability. Sometimes they were chosen for their color and asthetic quality, in the case of celts, primarily during the Neolithic period.

The first tool type, labeled "pounder-pestles/polishers" comprise tools with pecked-ground ends and/or one/two abraded (to a sheen/almost polished) faces (Figs 3a-c, fleft). This group consists of pebble- and cobble-size water worn pieces, under $10 \mathrm{~cm}$ in maximum dimension, made primarily of basalts and few examples of dolerite, gabbro, and amphibolite. The tools occur in a range of shapes: irregular, oblong, ovoid, rounded, as well as triangular- or square rounded. The attribute that distinguishes these tools from the others is the use-wear of pecked-ground ends, edges, or corners - as if the peckIng action was combined with an abrading motion. The use-wear indicates an action of pounding and crushing onto a stationary object, such as a quern or mortar. Several of the pieces also show evidence of a polished sheen on one or both faces. It is hard to determine whether this polish is a result of the oily residue of the hands onto the stone or burnishing of clay artifacts, such as pottery. They functioned as pounding and/or polishing tools.

The second tool type consists of facetted implements of sub-spherical and sub-cuboid shape (Figs $3 \mathrm{~g}-\mathrm{h}$ ). This tool group, labeled "facetted tools", consist of pebbles and small-sized cobbles of mostly irregular-rounded shape and some of (sub)-spherical and sub-cuboid shape created as a result of pecked, battered, and/or abraded/polished areas or facets, hence facetted tools. The majority of these are made from hard igneous stones, including basalt, dolerite, gabbro, and amphibolite. Several tools have an additional drill or gouge mark or "drag" (Blitzer 1995) across one surface, indicating a combined function of hand tool and wedging stone or drill holder The main action of these implements appears to be one of percussive as well as abrading/polishing action.

Polishers present another tool type, consisting of small cobbles with wear marks consisting of a polished face, for use as a polishing implement (Figs 3d-e,f right and middle). They are discshaped -rounded and flat - with additional pecked-ground circumference. Made from basalt, striations are visible on the polished face due to heavy polishing action. The raw materials employed clearly indicate their use as heavy abrasion, since they are of very hard igneous rocks.

Celts or axes always occurred in a variety of rock types throughout Crete, shaped mainly from igneous rocks (Fig. 3k). They are small and the large end was bevelled with evidence of pecking and/or chipping from use. The celts from Vronda, Kastro and Halasmenos are made from gabbro and basalt. Celts of this type have been found at Knossos and Myrtos and are common during the Neolithic period continuing into the EM period (Strasser pers. com., Warren 1972). There are examples from later contexts at Knossos and Karphi, but it seems likely that these tools were rediscovered and perhaps reused (Pendlebury et al. 1937-1938, Evely 1984). Of interest are two Neolithic axes made of granodiorite reported from Knossos (Strasser and Fassoulas 2003-2004). It appears that both came from the Mirabello bay region, based on the macroscopic characteristics given - medium-grained constitution of three minerals of white feldspar, gray quartz, and black hornblende and biotite occurring accidentally in some examples.

The last type of tool is distinguished by sub-cuboid and sub-spherical pebbles/cobbles with their entire surface pecked or pecked-ground (Fig.31-m). The entire surface is pecked or pecked-ground giving its regular appearance. Their size varies little between $7.5-5.3 \mathrm{~cm}$ in maximum dimension. It seems as if these tools made of gabbro and dolerite were deliberately shaped for a specific but yet unknown purpose, perhaps as "balance weights". 

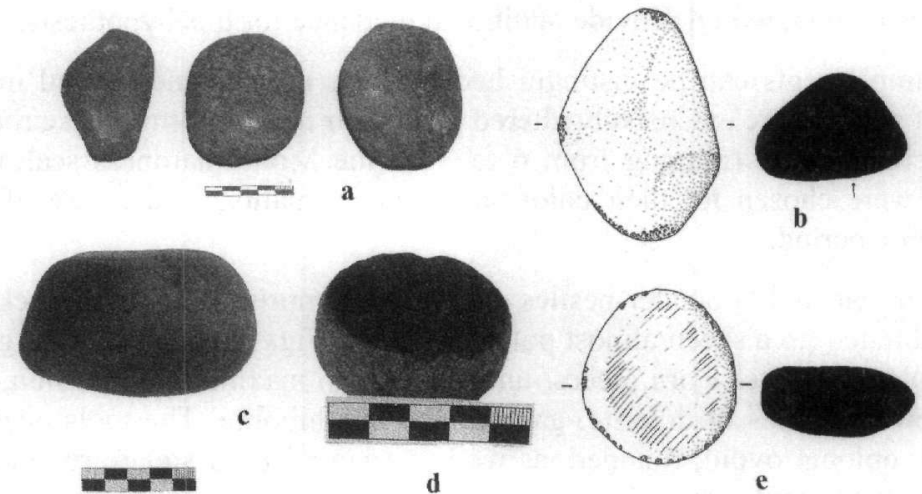

d

e
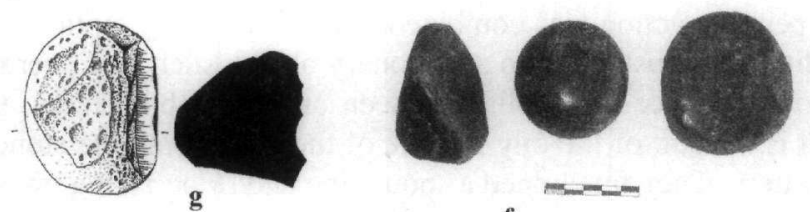

f
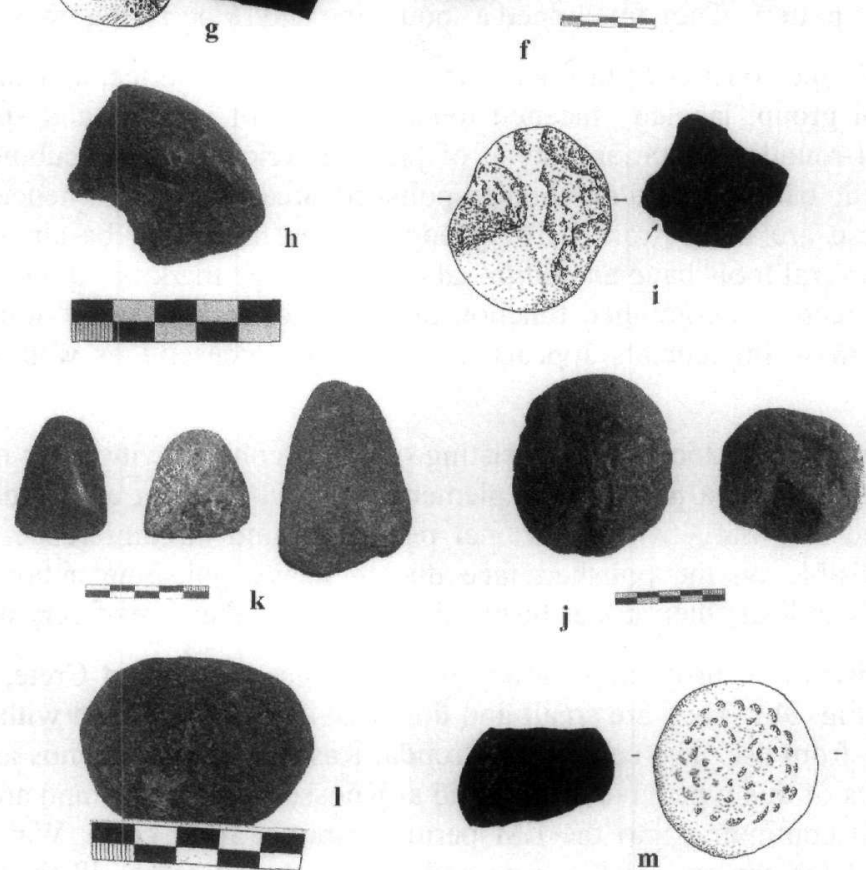

Figure 3 - Stone implements from Vronda, Kastro and Halasmenos. a,b,c,f : basalt; d,e: dolerite; g,h,i,j,l,m: gabbro; k: basalt , gabbro, and emery. Scale 1:3 for drawings

At present, all the above-mentioned tool types are represented mainly at the following sites: Vronda and Kastro (18\% and $14 \%$ of the total ground stone tool assemblages respectively) and Halasmenos ( $23 \%$ of the total ground stone tool assemblage), all of which can be dated to the Late Minoan IIIC and/or into the Iron Age (Table 1). Examples also occurred from the Neo-palatial sites at Pseira and Mochlos (Dierckx 1995, 1998a, 1998b, 1999, Carter 2004). The percentage of igneous and metamorphic rocks used as tools in the total assemblage is small however, less than $10 \%$. Moreover, at both sites, there is uncertainty as to the correct rock identification of the tools in question, which has been identified as mainly amphibolite. Also, the existence of an amphibolite source nearby, $2 \mathrm{~km}$ from Mochlos, from which much of the raw material reportedly 
came (Betancourt 1996, Myer and Betancourt 1998, Carter 2004), brings into question whether these two Neo-palatial sites should be included into this present study. For inclusion into this project, the evidence will be re-examined in the future.

Table 11 - List of tool types by raw material and sites. The \% reflects the amount of the total $\%$ of ground stone assemblage. Note: data for Halasmenos is based on preliminary results only

\begin{tabular}{|c|c|c|c|c|}
\hline Sites & Basalt & Dolerite & Gabbro & Amphibolite \\
\hline $\begin{array}{l}\text { Vronda } \\
\text { LMIIIC } \\
\text { Total nos: } 52 \\
18 \% \text { of total } \%\end{array}$ & $\begin{array}{l}28 \text { pounder- } \\
\text { pestles } \\
1 \text { facetted tool } \\
1 \text { polisher } \\
1 \text { celt }\end{array}$ & $\begin{array}{l}3 \text { pounder-pestles } \\
7 \text { facetted tools }\end{array}$ & $\begin{array}{l}4 \text { pounder-pestles } \\
5 \text { facetted tools } \\
1 \text { unknown } \\
1 \text { celt }\end{array}$ & None \\
\hline $\begin{array}{l}\text { Halasmenos } \\
\text { LMIIIC } \\
\text { Total nos: } 86 \\
23 \% \text { of total \% }\end{array}$ & $\begin{array}{l}61 \text { pounder- } \\
\text { pestes } \\
1 \text { facetted tool } \\
2 \text { polishers } \\
1 \text { celt }\end{array}$ & $\begin{array}{l}7 \text { pounder-pestles } \\
10 \text { facetted tools } \\
1 \text { celt }\end{array}$ & $\begin{array}{l}2 \text { pounder-pestles } \\
1 \text { polisher }\end{array}$ & None \\
\hline $\begin{array}{l}\text { Kastro } \\
\text { Early Iron Age } \\
\text { Total nos: } 58 \\
14 \% \text { of total } \%\end{array}$ & $\begin{array}{l}38 \text { pounder- } \\
\text { pestles } \\
1 \text { facetted tool } \\
3 \text { polishers }\end{array}$ & $\begin{array}{l}1 \text { pounder-pestle } \\
3 \text { facetted tools } \\
2 \text { unknown }\end{array}$ & $\begin{array}{l}2 \text { pounder-pestles } \\
3 \text { facetted tools } \\
1 \text { unknown } \\
2 \text { celts }\end{array}$ & $\begin{array}{l}1 \text { pounder- } \\
\text { pestle } \\
1 \text { facetted tool }\end{array}$ \\
\hline
\end{tabular}

\section{Conclusions}

Several pebbles and cobbles collected from the Mirabello Bay in NE Crete, show clear signs of their use as tools during Late Minoan IIIC and early Iron Age period in the inland settlements. They comprise mostly of dolerite, basalt, gabbro and amphibolite, all of which have the proper hardness of around 6-7 on the Mohs' scale. A Miocene onlap conglomerate, as well as stream deposits, draining it, contain plenty of pebbles and cobbles of analogous lithologies, which moreover have a proper size, i.e. are able to fit in one hand, to had been used as tools. Comparative petrographic study of natural samples from these two formations and the stone implements found at archaeological sites revealed that the pebbles/cobbles show significant similarities to the tool rocks, thus indicating that the onlap conglomerate and the stream pebbles may have been the sources for the Minoans from Vronda, Kastro, and Halasmenos gathering stone material for their implements. The evidence also seems to indicate that, subsequent to the Neo-palatial period, at a time when many sites start being located further from the sea and into the hills, the population deliberately went out of their way to obtain these specific rocks from the Kalo Chorio/Istron area. All three sites of Vronda, Kastro, and Halasmenos, are located at about 12-15 km from the source (Fig. 1), a one-day's walk, indicating the importance of finding durable and hard rocks for use as tools. It also suggests that the ancient Minoans were extremely knowledgeable about their environments and surrounding landscape and about the type of the material they needed each time for each type of intended implement, so to best manage their time for working-out these materials.

\section{Acknowledgments}

This work was financially supported by the Institute of Aegean Prehistory Study Center of East Crete. The authors are grateful to M. Tsipopoulou, W. Coulson, L. Day, G. Gesell and P. Betancourt for permission to study the material for this research. Critical reviews of the manuscript by Dr. Ir. Ronald Dierckx and two anonymous reviewers are greatly appreciated. 


\section{References}

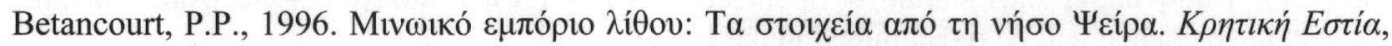
$5,47-70$.

Blitzer, H., 1995. Minoan stone implements and industries. In J.W. Shawand M.C. Shaw (eds), Kommos I. The Kommos Region and Houses of the Minoan Town, 1. The Kommos Region, Ecology and Minoan Industries. 403-535, Princeton University Press, Princeton.

Campbell, H.K., Craddock, J.P., and Klein, T.H., 2003. Calcite twinning constraints on alpine nappe emplacement, hellenic arc, Crete, Greece, Geological Society of America Annual Meeting, November 2-5, 2003, Seattle, USA.

Carter, T., 2004. The Stone Implements. In J.S. Soles and C. Davaras (eds), Mochlos IC. Period III. Neopalatial Setlement on the Coast. The Artisan's Quarter and the Farmhouse at Chalinomouri. The Small Finds, 61-107pp, Instap Academic Press, Philadelphia.

Dierckx, H.M.C., 1995. The ground and chipped stone tools. In P.P. Betancourt and C. Davaras (eds), Pseira I. The Minoan Buildings on the West Side of Area A..8-10,21-22,41-42,5556,64-65,81-82,96-97,124-126,142, University Museum Monograph 90, University of Pennsylvania, Philadelphia.

Dierckx, H.M.C., 1998a. The ground and chipped stone tools. In C.R. Floyd (ed.), Pseira III. The Plateia Building, 297-300pp, University Museum Monograph 102, University of Pennsylvania, Philadelphia.

Dierckx, H.M.C., 1998b. The ground and chipped stone tools, Building AC. In Betancourt P.P. and C. Davaras (eds), Pseira II. Building AC ('The Shrine') and Other Buildings in Area A. 27-29,87,91-92,95,100, University Museum Monograph 94, University of Pennsylvania, Philadelphia.

Dierckx, H.M.C., 1999. The Stone Tools. In P.P. Betancourt and C. Davaras (eds), Pseira IV. Minoan Buildings in Area B, C, D, and F. 8,14-16, 34-5,54,79-80,98,108, 125, 155-158, 183-4,195-6,203, 216-221, 234,280-281, University Museum Monograph 105, University of Pennsylvania, Philadelphia.

Evely, D., 1984. The other finds of Stone, Clay, Ivory, Faience, Lead etc. In M. Popham et.al. The Minoan Unexplored Mansion at Knossos. 223-259, Annual of the British School at Athens, Supplement 17, Oxford.

Fassoulas, C., Kilias, A., and Mountrakis, D., 1994. Postnappe stacking extension and exhumation of high-pressure/low-temperature rocks in the island of Crete, Greece, Tectonics, 13, 127 238.

I.G.M.E., 1959. Geological map of Greece, 1:50,000, Ierapetra sheet, Athens.

Jolivet, L., Goffé, B., Monié, P., Truffert-Luxey, C., Patriat, M., and Bonneau, M., 1996. Miocene detachment in Crete and exhumation P-T-t paths of high pressure metamorphic rocks, Tectonics, 15, 1129-1153.

Killias, A. Fassoulas, C., and Mountrakis, D., 1994. Tertiary extension of continental crust and uplift of Psiloritis metamorphic core complex in the central part of the Hellenic Arc (Crete, Greece), Geologisches Rundschau, 83, 417-430.

Klein, T.H., Zulauf, G., Craddock, J.P., and Heidelbach, F., 2004. Metamorphic Tripolitza rocks on top of non-metamorphic sediments: consequences for the geological evolution of Crete, $10^{\text {th }}$ International Congress of the Geological Society of Greece, 15-17 April 2004, Thessaloniki, Greece, Abstracts. 
Koepke, J., Kreuzer, H., and Seidel, E., 1985. Ophiolites in the southern Aegean arc (Crete, Karpathos, Rhodes)-Linking the ophiolite belts of the Hellenides and the Taurides. Ofioliti, $10,343-354$.

Myer, G.H., and Betancourt, P.P., 1998. "Analysis of the amphibolite". In C.R. Floyd (ed.), Pseira III. The Plateia Building, 173pp, University Museum Monograph 102, University of Pennsylvania, Philadelphia.

Pendlebury, H.W., Pendlebury, J.D.S., and Money-Coutts, M.B., 1937-1938. Karphi. A City Refuge of the Early Iron Age in Crete, BSA, 38, 57-148.

Seidel, E., Okrusch, M., Kreuzer, H., Raschka, H., and Harre, W., 1981. Eo-Alpine metamorphism in the uppermost unit of the Cretan nappe system, petrology and geochronology, Part 2. Synopsis of the high-temperature metamorphics and associated ophiolites, Contributions to Mineralogy and Petrology, 76, 351-361.

Seidel, E., Kreuzer, H., and Harre, W., 1982. A Late Oligocene/Early Miocen high pressure belt in the external Hellenides, Geologisches Jahrbuch, E23, 165-206.

Strasser, T., and Fassoulas, Ch. G., 2003-2004. Granodiorite Axes from Knossos and their Implications for Neolithic Trade on Crete, Aegean Archaeology, 7, 9-12, Warsaw.

Stöckhert, B, Wachmann, M., Küster, M., and Bimmermann, S., 1999. Low effective viscosity during high pressure metamorphism due to dissolution precipitation creep: the record of HP/LT metamorphic carbonates and siliciclastic rocks from Crete, Tectonophysics 303, 299-319.

Theye, T., and Seidel, E., 1993. Uplift-related retrogression history of aragonite marbles in western Crete (Greece), Contributions to Mineralogy and Petrology, 114, 349-356.

Theye, T., Seidel, E., and Vidal., O., 1992. Carpholite, sudoite and chloritoid in low-temperature high-pressure metapelites from Crete and the Peloponnese, Greece, European Journal of Mineralogy, 4, 487-507.

Warren, P., 1972. Myrtos: An Early Bronze Age Settlement in Crete. Annual of the British School at Athens, Supplement 7, London.

Zulauf, G., Kowalczyk, G., Krahl, J., Petschick, R., and Schwanz, S. 2002. The tectonometamorphic evolution of high-pressure low-temperature metamorphic rocks of eastern Crete, Greece:constraints from microfabrics, strain, illite crystallinity and paleostress, Journal of Structural Geology, 24, 1805-1828.

\section{Appendix. Lithic Terminology}

pecking/pecked - repeated percussive and pounding action resulting in small overlapping superimposed circular depressions

Abrading/abraded - rubbing/grinding action resulting in the smoothing and wearing down of the
working face resulting either in a ground surface (grinding stage) or lustrous surface (polishing
stage)

Battered - heavy percussive action resulting in detachment of layered flakes and pieces of rock combined with crushed surface areas 